\title{
Roles of transcriptional factor 7 in production of inflammatory factors for lung diseases
}

\author{
Yichun Zhu, William Wang and Xiangdong Wang*
}

\begin{abstract}
Lung disease is the major cause of death and hospitalization worldwide. Transcription factors such as transcription factor 7 (TCF7) are involved in the pathogenesis of lung diseases. TCF7 is important for T cell development and differentiation, embryonic development, or tumorogenesis. Multiple TCF7 isoforms can be characterized by the full-length isoform (FL-TCF7) as a transcription activator, or dominant negative isoform (dn-TCF7) as a transcription repressor. TCF7 interacts with multiple proteins or target genes and participates in several signal pathways critical for lung diseases. TCF7 is involved in pulmonary infection, allergy or asthma through promoting T cells differentiating to Th2 or memory T cells. TCF7 also works in tissue repair and remodeling after acute lung injury. The dual roles of TCF7 in lung cancers were discussed and it is associated with the cellular proliferation, invasion or metastasis. Thus, TCF7 plays critical roles in lung diseases and should be considered as a new therapeutic target.
\end{abstract}

Keywords: Lung disease, TCF7, TCF-1, Signal pathways

\section{Background}

Lung diseases are significant causes of death, of which chronic obstructive pulmonary disease (COPD), lower respiratory infection, or lung cancers are, respectively, ranked the number 3,4 , or 5 th as the top 10 causes of death in 2012 globally, with the number of deaths as 3.1 million, 3.1 million and 1.6 million respectively [1]. In China, lung diseases are the fourth cause of death in 2012 , with death rate at $75.59 / 100,000$ in urban area, and $103.9 / 100,000$ in rural area, and became the top one reason for hospitalization. The first cause of death in China is the malignant neoplasm, among which lung cancer is the most common one, causing a total death rate of $49.73 / 100,000$ in urban area and 38.78/100,000 in rural area [2]. There are many types of lung diseases including obstructive lung diseases, infectious illnesses, lung cancer, respiratory failure, pulmonary edema, pulmonary

\footnotetext{
*Correspondence: xiangdong.wang@clintransmed.com Shanghai Respiratory Research Institute, Zhongshan Hospital, Fudan University Center for Clinical Bioinformatics, Fenglin Rd 180, Shanghai 200032, China
}

embolism, pulmonary fibrosis and sarcoidosis, as well as occupational diseases.

Transcription factors as nuclear proteins bind to specific DNA sequences and regulate the transcription process of the gene, consisting of the largest family of human proteins encoded by about $8 \%$ of genes in human genome [3]. The specific DNA sequences binding to the transcription factors become the enhancer or promoter regions of the genes regulated. Transcription factors play the role in the regulation of the gene transcription through stabilizing or blocking the recruitment of RNA polymerase to specific genes, the catalysis of the acetylation or deacetylation of histone proteins, and the recruition of coactivator or corepressor proteins to the transcription factor DNA complex [4-6]. Transcription factors are critical for a huge number of cellular processes such as growth, development, and differentiation by regulating the gene expression [7]. Mutations of transcription factors were found in human diseases, and were considered as drugable targets for drug discovery and development $[8,9]$.

Transcription factor 7 (TCF7), also known as T-cellspecific transcription factor-1 (TCF-1), is a member of transcription factors. The recent paper overviewed the 
biology and functions of transcription factor 7 (TCF7), its interactions with other proteins in several critical pathways, and potential roles in lung diseases. We will explore the important role of TCF7 in pathogenesis, diagnosis, or therapies for lung diseases.

\section{Review \\ Understanding the dual biological functions of TCF7 Structure and location}

TCF7 gene was firstly identified as a T lymphocyte-specific transcription factor in 1991, and belongs to a large DNA binding protein family called high-mobility group (HMG) box [10, 11]. The TCF7 gene resides on human chromosome 5q31.1 and named as TCF7 at the Human Gene Mapping 11 workshop [12]. TCF7 gene contains multiple exons, of which different splicings transcribe to variants of mRNAs. There are two promoters, four alternative exons (exon1a, 1b, 4a, and 9), and three splice acceptors in the exon 10 of TCF7 gene, while 96 different mRNAs could be theoretically translated [13]. At least 16 different protein isoforms with distinct functional properties have been found. mRNAs transcribed from the two different promoters can translate to two groups of proteins with different functions. The first promoter generates mRNA encoding a full-length activating form (FL-TCF7) (42-60 kDa), while the second intronic promoter produces a truncated, dominant-negative isoform of TCF7 (dnTCF7) (25-40 kDa) [14, 15]. The long isoforms contain a C-terminal DNA-binding domain named HMG box (encoded by exons 6 and 7), a Groucho binding domain, as well as an $\mathrm{N}$-terminal $\beta$-catenin-binding domain (encoded by exon 1a and 1b), while the short isoforms lack of the $\beta$-catenin-binding domain $[13,16-18]$ (Fig. 1).

TCF7 was initially found to be expressed exclusively in T lineage lymphocytes [10], and the level of TCF7 was high in thymocyte cells and peripheral naive $\mathrm{T}$ cells, but was undetectable in effector $\mathrm{T}$ cells $[13,15$, 19]. After then, TCF7 was also found in other tissues in embryonic period, mainly in neuroectodermal cells and differentiating mesenchymal cells. The expression of TCF7 seemed to be "shut off" around birth in nonlymphoid tissues [20], while TCF7 was over-expressed in malignant tumors, e.g. colorectal cancers [21], prostate cancers [22], or breast cancers [23], in addition to lymphomas and leukemia derived from $\mathrm{T}$ lymphocyte [19, 24]. However, a number of studies demonstrated that TCF7 might act as a tumor suppressor and be diminished in leukemia [25, 26], lymphomas [27], or colorectal cancers [28]. The dual roles of TCF7 in tumorogenesis could be explained by the different functions of variant isoforms of TCF7 and the complexity of tumor variations with multiple signaling pathways in the process of tumor development. The distribution of different TCF7 isoforms was found to vary between tumors and normal tissues in colon cancers or mammary tumors $[29,30]$. It was detected that the dominant TCF7 isoform had short-life and existed in both nucleus and plasma in normal cells such as proliferating intestinal epithelial cells and basal epithelial cells of mammary gland epithelium, while the full-length isoform in tumor cells and mainly appeared in plasma. The balance between the full- and short-length isoforms seems to be a checkpoint for promoting or inhibiting tumor genesis and development.

\section{Regulating and regulated roles of TCF7 gene}

The expression of TCF7 gene is regulated by a number of factors through multiple signaling pathways. TCF7 is enhanced by $\beta$-catenin and TCF7L2 (also known as TCF4) as a downstream target gene of Wnt pathway. Two TCF-binding motifs were found at $1.2 \mathrm{~kb}$ upstream of promoter I of TCF7 gene on a CpG island that acts as an enhancer. The enhancer can be trans-activated by the combination of $\beta$-catenin and TCF7L2, while the dominant negative isoform of TCF7L2 could inhibit the transcription. TCF7 represses the target genes of $\beta$-catenin and TCF7L2, forming a negative feedback loop (Fig. 2). The process can be regulated through the counteraction of dnTCF7 with TCF7L2 target genes such as c-myc and cycline D1 [30]. TCF7 promoters do not contain the A/

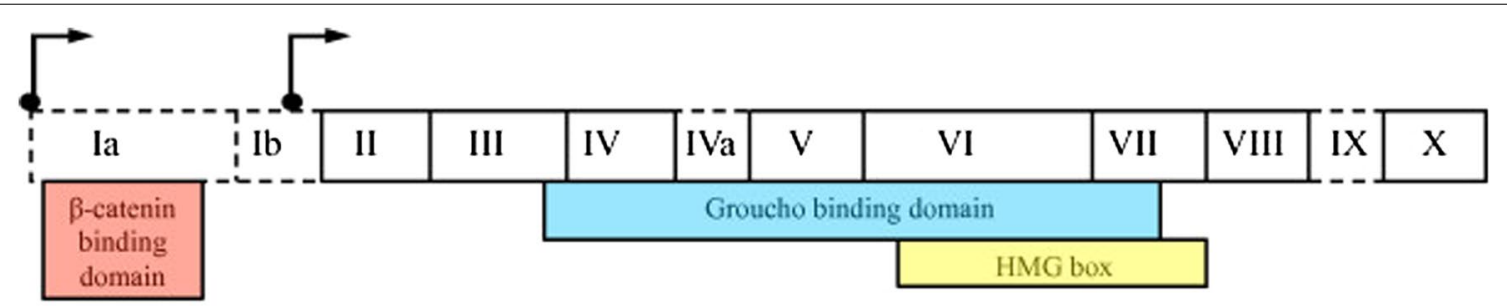

Fig. 1 TCF7 gene structure. TCF7 gene contains multiple exons. Different splicing may transcribe to variants of mRNAs, and translates to different protein isoforms. Exon la, Ib, IVa, and IX are alternative exons. There exits two promoters as shown in the figure. The first promoter can generate mRNAs encoding a full-length activating form of protein isoforms which contains the $\beta$-catenin binding domain, while the second promoter cannot and thus produce the truncated dominant-negative isoforms. Therefore, two different groups of TCF7 isoforms function differently. 


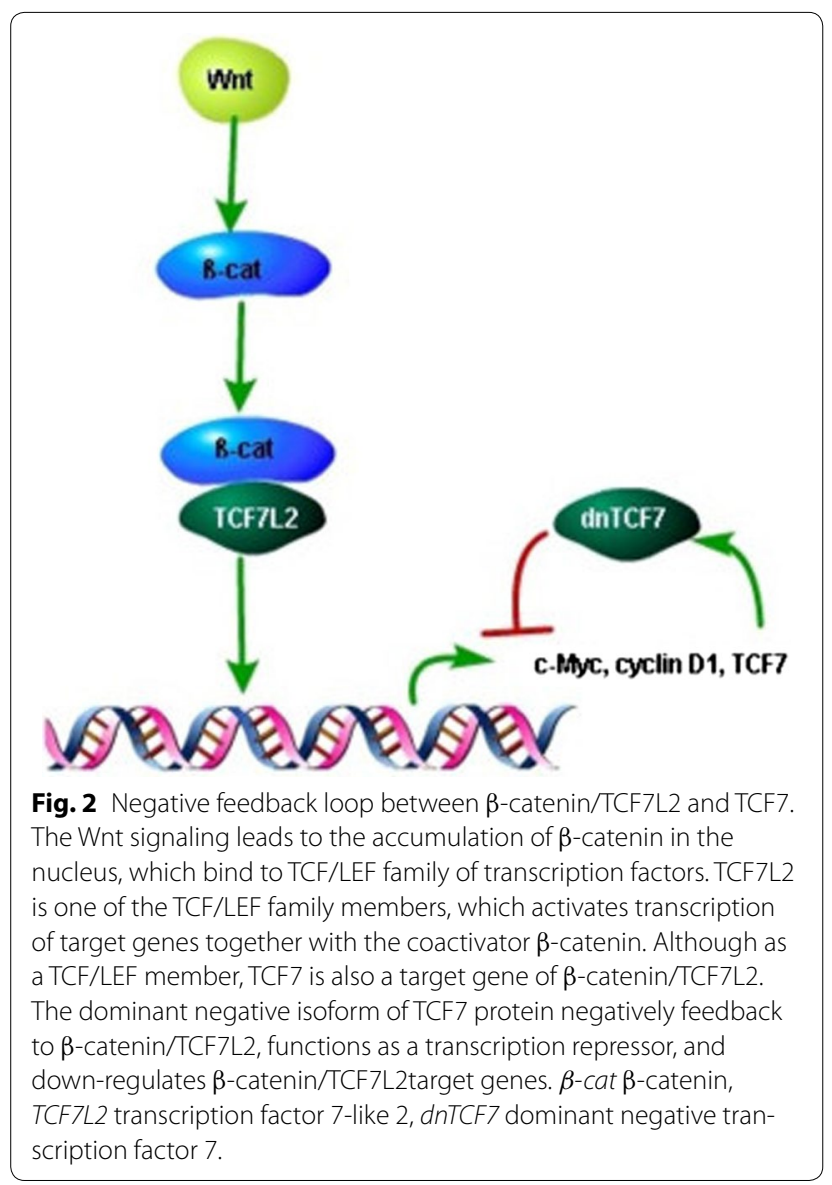

TA/TCANA G binding motif that can interact with TCF7 protein, therefore people used to consider that TCF7 could not be autoregulated [18]. But recent studies found that TCF7 could bind to the TCF7 locus and induce TCF7 gene expression [31].

TCF7 may be involved in the $\mathrm{T}$ cell differentiation, evidenced by the finding that TCF7 expression highly expressed in naive $\mathrm{T}$ cells, down-regulated in effector $\mathrm{T}$ cells, and up-regulated again in memory $\mathrm{T}$ cells in the process of $\mathrm{T}$ cell differentiation [32]. TCF7 was proposed to regulate the activation of $\mathrm{T}$ cells and the production of their cytokines, and be simultaneously regulated by TCR stimulation and cytokines such as IL-4, IL-2, IL-15, IL-7 and IL-12 in human naïve CD8 T cells, especially through the dnTCF-1 isoform $[15,17,33]$. T cell cytokines could inhibit the inhibitory isoform of TCF7 and then facilitate the activation of naïve $\mathrm{T}$ cells into effector $\mathrm{T}$ cells, since TCF7 functions as a promoter factor in $\mathrm{T}$ cell differentiation.

\section{Dual roles of TCF7 in transcription}

TCF7 protein is generally known as a transcription factor. FL-TCF7 functions as a transcription activator, while
dnTCF7 acts as a transcription repressor. Both isoforms of TCF7 could bind with Groucho co-repressors and act as a transcription repressor without $\beta$-catenin signaling, while FL-TCF7 could interact with $\beta$-catenin and induce the transcriptional activation when $\beta$-catenin accumulating in the nucleus. The dnTCF7 isoform lacks the $\mathrm{N}$-terminal $\beta$-catenin binding domain and was proposed to play a negative role in transcription regulation [34]. The FL-TCF7 was considered to have dual functions in regulating gene transcription through the interaction with different proteins. In addition to Groucho family proteins, the $\beta$-catenin/TCF7-mediated transcription process could also be interfered directly by a multidomain protein, Bcr (breakpoint cluster region), to dissociate $\beta$-catenin/TCF7 complex and down-regulate the level of $\beta$-catenin/TCF7 target genes such c-Myc $[35,36]$, as shown in Fig. 3. Exogenous aptamers can also affect the formation of $\beta$-catenin/TCF7 complex, for example, RNA aptamer could specifically bind to TCF7 and inhibit its binding to $\beta$-catenin [37].

\section{Role of TCF7 in the development of T cells and ILC2}

TCF7 is an important factor for the development and differentiation of T-lineage cells, both in the thymus and the peripheral. Progenitor $T$ cells in thymus undergo several stages and differentiated into naïve $\mathrm{T}$ cells and migrate to the peripheral. The peripheral naïve $\mathrm{T}$ cells then undergos another differentiation upon antigen encounter, and become effector T cells [38]. TCF7 is found highly up regulated in early thymic progenitors (ETPs), promotes the expression of T-lineage genes, and is critical for $\mathrm{T}$ cell specification. Although TCF7

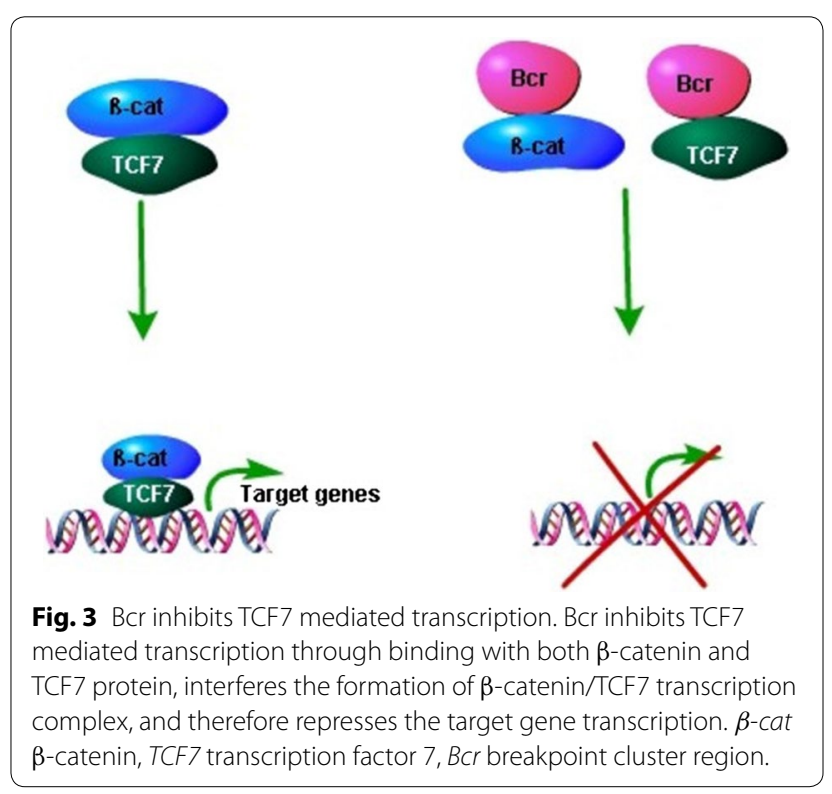


usually promotes gene transcription with the co-activator $\beta$-catenin, evidence showed that the function of TCF7 in early $\mathrm{T}$ cell development is not relied on Wnt/ $\beta$-catenin pathway $[39,40]$, but is closely associated with the activation of Notch signaling [31]. Even so, Wnt/ $\beta$-catenin/TCF7 pathway is still involved in multiple stages of $\mathrm{T}$ cell development, supports proliferation of DN thymocytes, promotes DN to DP transition, enhances DP thymocyte survival and participates in positive/negative selection [38]. As in the peripheral, TCF7 was considered as a contributor for Th2 but suppressor for Th1 or Th17 cell fate in CD4+ $\mathrm{T}$ cells [17, 41-43], and also promotes the formation of memory cells in CD8+ T cells [44] (Fig. 4).

Group 2 innate lymphoid cells (ILC2) are a kind of innate lymphocytes that functionally produce Th2 cell associated cytokines and mediate innate type $2 \mathrm{immu}-$ nity $[45,46]$. A recent study demonstrated that TCF7 is required for the development of ILC2 cells, through both GATA-3-dependent and GATA- 3-independent pathways [47].

\section{Biological interactions with others Interactions with CD3E}

CD3E gene encodes CD3- $\varepsilon$ polypeptide, which forms the T-cell receptor-CD3 complex together with CD3- $\gamma,-\delta$ and $-\zeta$, and the T-cell receptor $\alpha / \beta$ and $\gamma / \delta$ heterodimers. TCF7 recognizes the motif sequenced as AACAAAG in the enhancer of CD3E gene, and induces the T-cellspecific expression of CD3- $\varepsilon$ polypeptide. TCF7 was also found to be able to interact with TCR- $\alpha$, TCR- $\beta$ and TCR- $\delta$ enhancers. TCF7 could promote the formation of the TCR/CD3 complex, and act as a key factor in T cell development [10]. The low expression of CD3- $\varepsilon$ was noted in both CD4+ T and CD8+ T cells from peripheral blood and pleural effusion of lung adenocarcinoma patients. Previous studies showed that NSCLC cells could induce the down-regulation of CD3- $\varepsilon$ in Jurkat $\mathrm{T}$ cells which might be responsible for T-cell anergy in lung cancer [48]. It is possible that the down-regulation of CD3- $\varepsilon$ in patients with lung cancer may be related to TCF7 dysfunction through the regulation of TCF7 in CD3E expression.

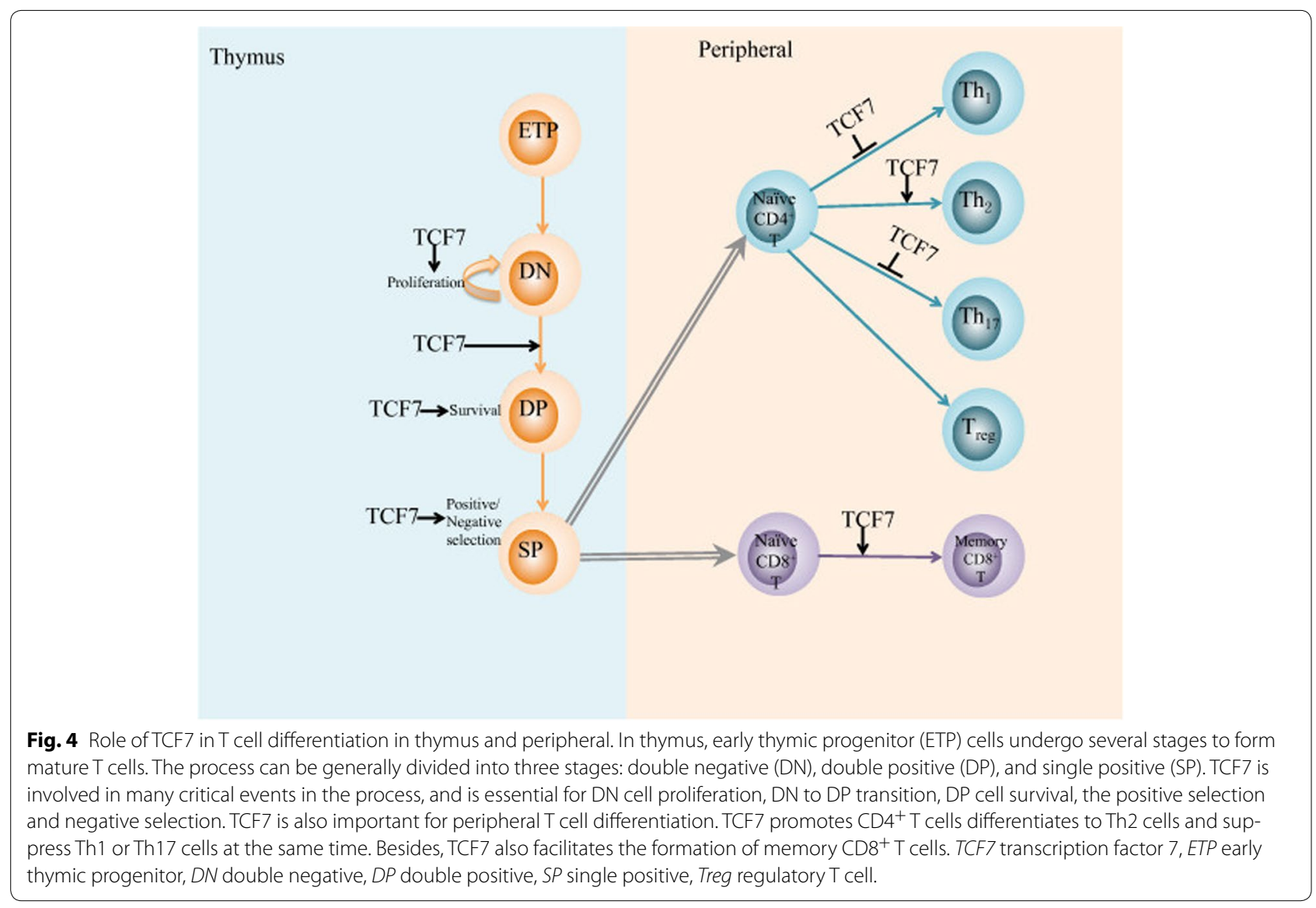




\section{Interactions with $\beta$-catenin}

$\beta$-catenin, encoded by the CTNNB1 gene on human chromosome 3p21, is a key protein in canonical Wnt pathway [49], as shown in Fig. 5. Activation of Wnt signaling results in the accumulation and/or translocation of the downstream $\beta$-catenin in cytosol and/or nucleus, to form an active transcription complex with TCF/LEF family members including TCF7, TCF7L1, TCF7L2 and LEF1 [50]. $\beta$-catenin binds to TCF7 at the $N$-terminal $\beta$-catenin binding domain, which only exists in the full-length isoform of TCF7. The $\beta$-catenin/TCF7 signaling was reported as an important pathway in regulating $\mathrm{T}$ cell development, differentiation, or survival $[38,51]$. TCF7 gene can encode a protein to form the transcription complex with $\beta$-catenin and act as a target gene of $\mathrm{Wnt} / \beta$-catenin signaling, which could be enhanced by $\beta$-catenin/TCF7L2, together with Myc, Cyclin D1, PPAR- $\delta$, MMP-7, Axin2 , or CD44, etc. $[30,50]$. There might be a negative feedback loop whenTCF7 repressed $\beta$-catenin target genes [30].

\section{Interactions with TCF7L2}

TCF7L2, also known as TCF4, is another member of TCF family. There still remains a significant variation between TCF7L2 and TCF7, although both proteins function as transcription factors that bind to the coactivator $\beta$-catenin to up-regulate the transcription of target genes. The two proteins can interact with each other and form a regulation loop, as shown in Fig. 2. TCF7L2 binds to and transactivate the enhancer of TCF7 gene with the coactivator $\beta$-catenin and promotes TCF7 transcription, while TCF7 down-regulates TCF7L2 target genes and acts as a feedback repressor of $\beta$-catenin/TCF7L2 with a potential function of tumor suppressor [30]. High expression or mutations of TCF7L2 were found in several human tumors such as colorectal cancer [52], breast cancer [53], liver carcinoma [54], or lung cancer [55]. TCF7L2 was suggested to play an important role in the pathogenesis of NSCLC. However, a recent meta-analysis came to a contradictory conclusion that there is no association between TCF7L2 polymorphism with lung cancer [56]. The potential tumor-genesis role of TCF7L2 suggested

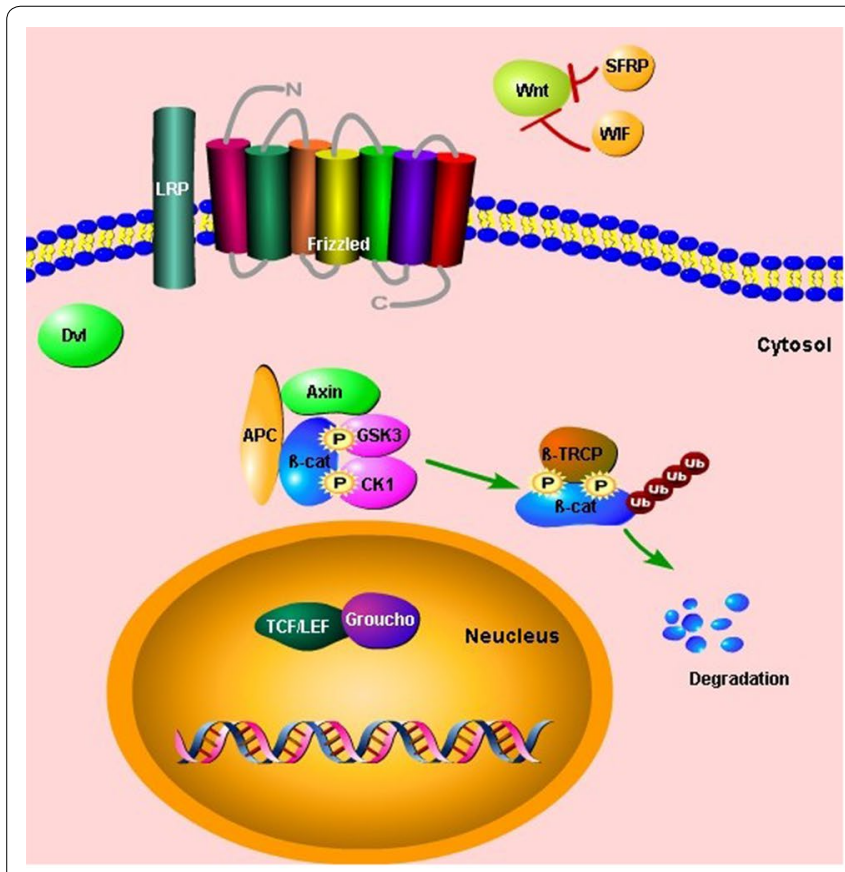

a Wnt off

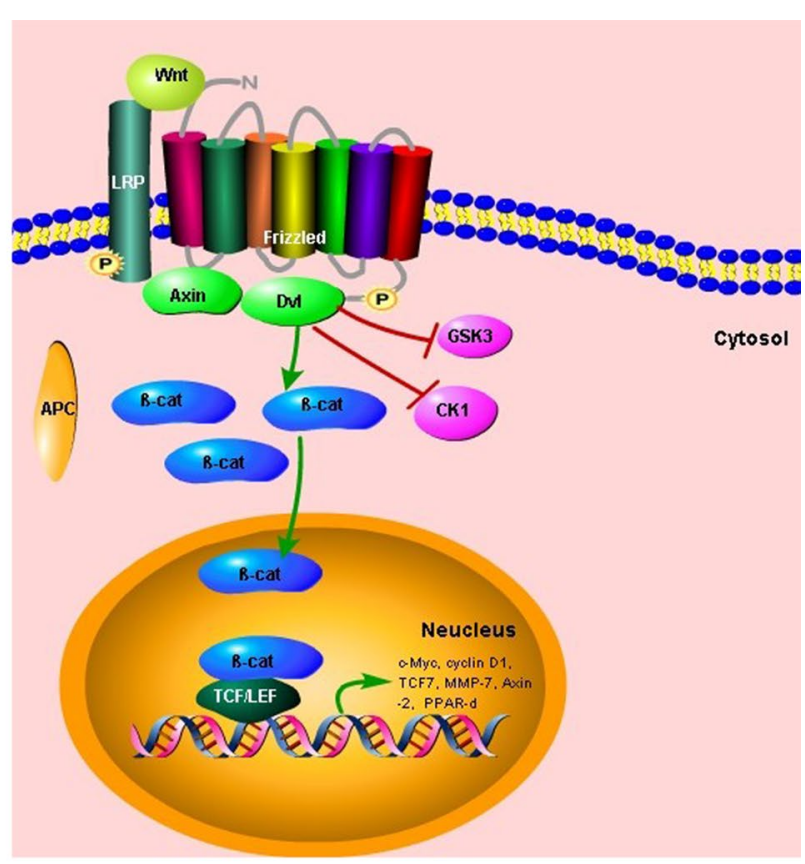

b Wnt on

Fig. 5 The canonical Wnt pathway. a Wnt is naturally inhibited by inhibitors such as SFRP and WIF. Without a Wnt signal, the $\beta$-catenin is captured by APC and Axin, then CK1 and GSK3 phosphorilate $\beta$-catenin, leading to proteasomal degradation. Without $\beta$-catenin binding, the TCF/LEF family proteins bind with Groucho family proteins, and function as a transcription inhibitor. b When Wnt signaling activated, Wnt binds to specific FrizzledLRP complexes on the cell surface and initiate the canonical Wnt pathway. The activated receptor complex phosphorylates Dvl. Then Dvl inhibits CK1 and GSK-3, resulting in the accumulation of non-phosphorylated $\beta$-catenin in cytoplasm, which cannot be ubiquitinylated for degradation. $\beta$-catenin then translocates into the nucleus, and binds with TCF/LEF, causes transcriptional activation of target genes. $\beta$-cat $\beta$-catenin, LRP lowdensity lipoprotein receptor-related protein, CK1 casein kinase $1 \alpha, G S K-3$ glycogen synthase kinase-3 $\beta$, DVI disheveled, APC adenomatous polyposis coli, SFRP secreted Frizzledrelated protein, WIFWnt inhibitory factor, TCFT cell factor, LEF lymphoid enhancer-binding factor. 
a novel method in tumor therapies, which is to inhibit TCF7L2 expression or to down-regulate its target genes' expression. Since TCF7 could suppress TCF7L2, it might be a promising anti-tumor strategy to introduce TCF7 to tumor cells as a treatment.

\section{Interactions with LEF-1}

Lymphoid enhancer-binding factor 1 (LEF-1), also named TCF-1a, is another TCF family member and contains a DNA-binding HMG box acting as a transcription factor, similar to TCF7. LEF-1 expresses in T cells and pre-B cells to promote thymocyte maturation as a collaborator of TCF7 [57, 58]. As downstream factors in wnt/ $\beta$-catenin signaling, both TCF7 and LEF1 levels were up-regulated in some tumors such as colon cancers [59]. However, more recent studies found a restriction of LEF-1 in early thymocytes by the interaction with TCF7, so the malignant transformation of developing thymocytes could be prevented as a therapeutic target. LEF-1 is repressed directly by TCF7 through binding at TCF1 binding cluster (TBC), a cluster of three motifs located around $-4.4 \mathrm{~kb}$ in the Lef1 locus [25].

\section{Interactions with IL-17}

IL-17, which is an important cytokine involved in infection, autoimmune response and allergy, is mainly produced by Th17 cells to promote the formation of Th17 cells [60]. A special link between IL-17 and asthma has been concerned, especially IL-17A and IL-17F of the IL-17 family, which were shown to play a pro-inflammatory role in asthma and have the potential association with the disease severity [61]. IL-17A was also suggested to be correlated with other airway diseases such as COPD [62]. It was found that TCF7 could repress the expression of IL-17 gene through the direct binding with the promoter region and the second intron of the IL-17 gene locus. Such repression was proposed to have no association with the other factors involved in Th17 differentiation, such as ROR $\gamma \mathrm{t}$, Stat3, ROR $\alpha$, Ahr, Runx-1, Ets-1, Socs3, IRF4, or Batf. There was no connection with $\beta$-catenin either, although it acts as the co-activator of TCF-1 in many other cases [42]. Thus TCF7 could be a potential therapeutic target for asthma, COPD and other lung diseases associated with high-expression of IL-17 through inhibiting IL-17 expression.

\section{Interactions with IL-4}

IL-4 is a main Th2 cytokine to promote the differentiation of naïve $\mathrm{T}$ cells to Th2 cells, produced by Th2 cells, subsequently [63]. IL-4 can stimulate B cell function [64] and is associated with chemotaxis of monocytes, macrophages and eosinophils [65, 66]. Paradoxically, antiinflammatory functions of IL-4 was also found since it down-regulates TNF- $\alpha$, IL-1, IL-6, IL-12, PGE2, or IL-8, which are proinflammatory mediators [67]. IL-4 displays the dual role in the course of lung fibrosis, plays an anti-inflammatory role in initial stages of lung injury, and promotes collagen deposition during the later stages [68]. TCF7 can promote Th2 cell differentiation through transcriptional activation of GATA-3, mainly from the proximal GATA-3 promoter at the upstream of exon $1 \mathrm{~b}$. IL-4 produced by Th2 cells down-regulates the expression of TCF7 gene and functions as a suppressor of TCF7 in naïve human $\mathrm{CD} 4+\mathrm{T}$ cells, mainly through stimulation of STAT6 that interacts with specific DNA motifs of human TCF7 locus $[17,69]$. IL-4 mainly down regulates the short isoform of TCF7, which functions as a transcription repressor and inhibit TCF7-mediated Th2 differentiation, thus contributes Th2 differentiation (Fig. 6) [17].

\section{Interactions with Eomes}

Eomesodermin (Eomes) is a transcriptional factor involved in CD8+ T cell memory [70]. TCF7 directly and specifically binds to 6 conserved consensus sequences in the Eomes $5^{\prime}$-regulatory region, to induce its expression and promote the formation and maintenance of memory CD8+ $\mathrm{T}$ cells [44]. Memory CD8+ $\mathrm{T}$ cells in airways are involved in the immediate immune response to secondary virus challenge, and provide a protection from secondary infection [71]. Introducing TCF7 to the lung would probably be a therapeutic way to protect patients from secondary infections through enhancing eomes.

\section{Involvements of signal pathways \\ Wnt signal pathway}

The canonical Wnt pathway regulates a variety of cellular processes, including proliferation, differentiation,

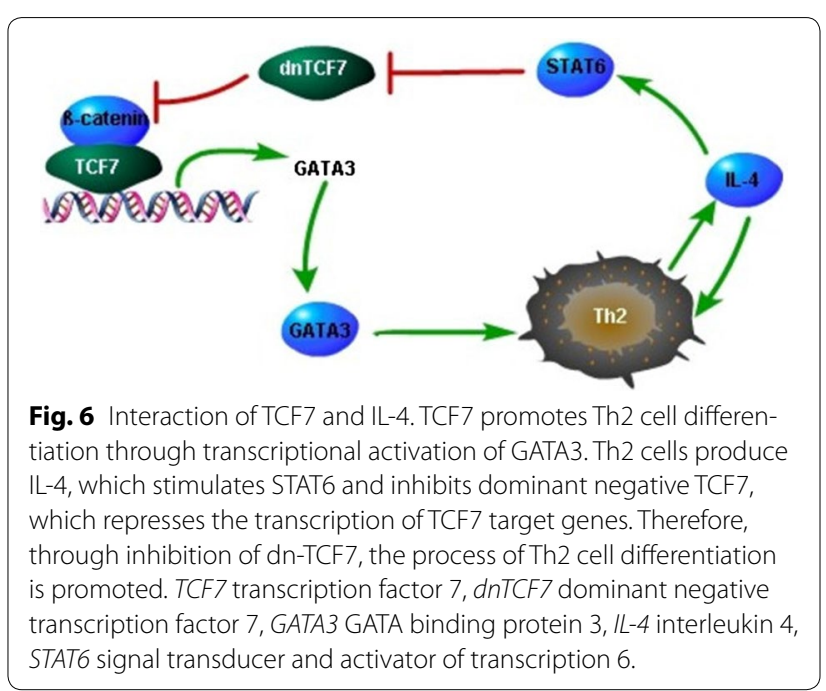


survival, apoptosis and cell motility, and plays an important role in lung morphogenesis, repair after injury, or carcinogenesis (Fig. 5) [72]. When Wnt pathway is activated, secreted signaling proteins of the Wnt family bind to specific Fzd-LRP (Frizzled-low-density lipoprotein receptor-related protein) receptor complexes on the cell surface and initiate the canonical Wnt pathway, leading to the intracellular accumulation of $\beta$-catenin [50]. The activated receptor complex phosphorylates cytoplasmic disheveled (Dvl) which then inhibits casein kinase $1 \alpha$ (CK1) and glycogen synthase kinase-3 $\beta$ (GSK-3). The activation of Dvl-CK1-GSK3 causes the failure of $\beta$-catenin degradation through ubiquitination and accumulation of non-phosphorylated $\beta$-catenin in cytoplasm. The stable $\beta$-catenin is then translocated into the nucleus to form an active transcription complex with TCF/LEF family members, resulting in activation of multiple target genes, such as c-myc, cyclin D1, matrix metalloproteinases (MMP2, MMP3, MMP7, and MMP9), Cox-2, c-jun, Fra-1, VEGFR, or TCF7 [73-82]. In the absence of Wnt ligand, TCF/LEF could repress the transcription of target genes through the interaction with Groucho family protein, and function as transcription repressors [34]. TCF7 also functions as a target gene of Wnt pathway. TCF7L2/ $\beta$-catenin could activate the transcription of TCF7, while the dominant negative isoform of TCF7 repressed target genes of TCF7L2/ $\beta$-catenin [30]. Therefore, different isoforms of TCF7 play totally different roles in the activation of Wnt signaling pathway.

The abnormality of Wnt signaling was proposed to be associated with the pathogenesis and development of lung diseases, e.g. cancer, fibrosis, or pulmonary arterial hypertension [79]. Activated Wnt signaling was found in NSCLC, with overexpression of Wnt proteins or Dvl, the lack of Wnt pathway repressors, e.g. WIF, sFRP1 and DKK3, or methylation of the promoter of APC, which binds and inhibits $\beta$-catenin [83-87]. Target genes such as LEF1 and HOXB9 were found to be related with the metastasis of lung adenocarcinoma [88]. The Wnt signaling might be also involved in the initial phase or in the ongoing multistep process of lung cancerogenesis [79]. However, the high level of $\beta$-catenin was found correlated with better prognosis in patients with NSCLC, which seems totally different from colon carcinomas or hepatomas [89-91]. The contradictory findings may be explained by the multi-function of $\beta$-catenin, which transduces canonical Wnt pathway and regulates cellular adhesion through the interaction with E-cadherin [91]. Overexpression of Wnt genes (WNT2 and $-5 a$ ), the receptors (FZD7 and -10$)$, WNT regulators (sFRP1 and -2 ), and Wnt target genes (MMP7) was reported in lung fibrosis [92-96], while the expression of TCF7 did not increase [97]. Wnt/ $\beta$-catenin signaling was suggested involved in the repair process after lung injury, characterized by a decrease of inflammation, re-epithelialization, and matrix remodeling. Increased nuclear $\beta$-catenin was found during the fibroproliferative phase after acute lung injury. In addition to the $\mathrm{Wnt} / \beta$-catenin signaling, the $\beta$-catenin/E-cadherin pathway was related with the repair process [98]. However, there were a number of contradictory reports that $\beta$-catenin was not necessary in the process of bronchiolar epithelium repair [99]. The paradoxical results may indicate the complexity of the disease pathology and the multiple roles of the Wnt pathway in lung diseases.

\section{Activation in FoxO1 signal pathway}

FOXO1 belongs to the forkhead family of transcription factors and contains a conserved forkhead domain which binds to specific DNA sequence and is involved in a number of cellular processes, including cell proliferation, apoptosis, differentiation, DNA damage or repair, and stress responses [100-102]. FOXO1 up-regulates p27 and p21 to down-regulate the cell cycle regulator cyclin D1, which results in the cell cycle arrest, and plays a potential role in tumor suppression [103]. FOXO1 expression was associated with an earlier stage of lung cancer, the less nodal involvement or venous invasion, or a favorable prognosis in NSCLC where apoptosis was induced by FOXO1 [104, 105].

FOXO1 plays an important role in the process of memory $\mathrm{T}$ cell differentiation. It activates the expression of TCF7, IL7r or Ccr7, through the direct interaction between the highly conserved forkhead-binding motif and the promoter region of the target genes [106]. FOXO1 could bind to multiple sites close to or within TCF7 gene of regulatory $\mathrm{T}$ cells and naive CD4+ T cells [107]. The activation of Akt phosphorylation could directly inactivate FOXO1 and down-regulate TCF7 expression [108].

\section{The importance of Notch signal pathway}

Notch pathway regulates critical cell fate decisions during both development and adult life [109], including the course of $\mathrm{T}$ cell development and differentiation, e.g. the decision of CD4+ $\mathrm{T}$ cells between the Th1 vs the Th2 fate [110]. TCF7 is one of the target genes of Notch to be up-regulated during the early development of $\mathrm{T}$ cells [31, 111]. Notch could directly activate TCF7 through the interaction with an enhancer $31.5 \mathrm{~kb}$ upstream of the TCF7 promoter, up-regulating the T-cell essential genes, including components of the TCR, or transcription factors Gata3 and Bcl11b [31]. Although TCF7 is the downstream of Notch, the consistent expression of TCF7, GATA3, or Bcl11b was independent on Notch, since TCF7 could positively auto-regulate and maintain 
the expression after the activation [31, 112]. It is probable that secondary factors other than Notch signaling were associated with the up-regulation of TCF7 and GATA3 expression during $T$ cell differentiation stages of the DN-DP transition [112, 113]. GATA3 expression promotes the differentiation of $\mathrm{T}$ cells to Th2 cells or innate lymphoid cells (ILCs). It was reported that TCF7 with its coactivator $\beta$-catenin negatively regulated Notch pathway in thymocytes at CD4-CD8-double-negatve 3 (DN3) stage or beyond. The expression and signaling of pre-TCR $\alpha$ as Notch targets was repressed by TCF7 [114], although the mechanism by which TCF7 mediated the repression of Notch remains unclear.

\section{The significance of $P 21$ signal pathway}

P21 is an important cyclin-dependent kinase (cdk) inhibitor and represses the G1-to-S phase transition mainly by inhibiting the activity of the cyclin E-cdk2 complex. P21 is related to tumor differentiation and acts as a significant factor predicting the prognosis of patients with NSCLC $[115,116]$. The growth arrest mediated by $\mathrm{p} 21$ was clarified to be dependent upon the activity of C-clamp, a DNA-binding domain other than HMGbox in the E-tail isoform of TCF1. HMG-box binds Wnt response elements (WREs), while the C-clamp contacts with $5^{\prime}$-RCCG-3'elements (where R is $\mathrm{G}$ or A) upstream or downstream of WREs. The C-clamp-RCCG interaction could induce the activation of $\mathrm{p} 21$ through the down-regulation of multiple p21 suppressor genes like RUNX1, SMARCA4, SP5, TGIF, or YAP1 at the transcription level, MSI2 at the RNA stability, or CUL4A at the protein stability. The up-regulation of p21 by dnTCF1E may subsequently cause a stall in the G1 phase of the cell cycle [117]. Other studies found that the p21 promoter could be inhibited by constitutively active TCF, and enhanced by dominant negative TCF. N-cadherin suppressed $\beta$-catenin/TCF, induced $\mathrm{p} 21$ expression, and lead to a decreased activity of cyclinB-Cdc2 kinase and G2/M arrest [118] (Fig. 7).

\section{Potential roles in the pathogenesis of lung diseases Pulmonary infection}

TCF7 is involved in the development or differentiation of $\mathrm{T}$ cells in the thymus or peripheral circulation, promotes the naïve CD4+ T cells into Th2 cells and accelerates the formation of memory $\mathrm{T}$ cells, which may provide the protective roles in pulmonary infection [38]. TCF7 was also associated with development or differentiation of natural killer cells or ILC2 cells [47]. There is a need of the direct evidence to show the involvement of TCF7 in the development of pulmonary infection, even though TCF7 may have the close relationship with key lymphocytes in immune responses against infection.

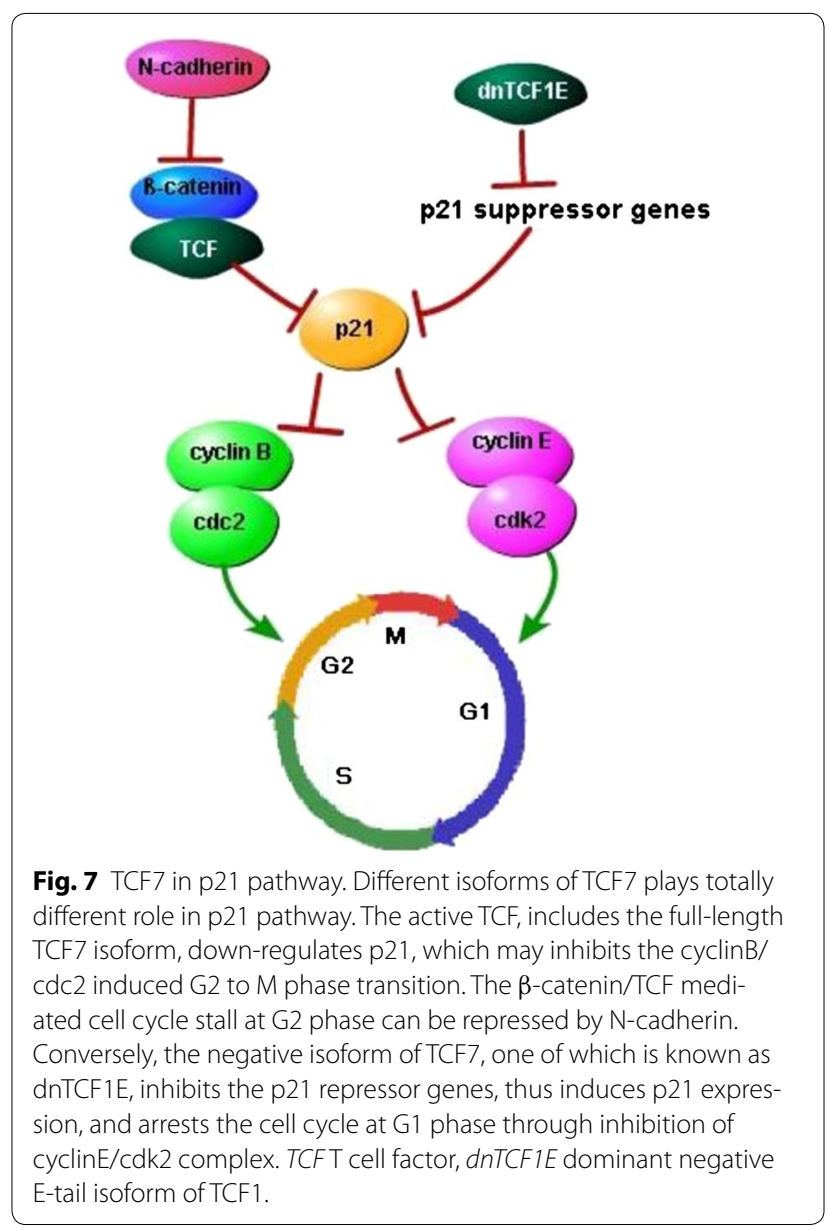

\section{Pulmonary inflammation}

TCF7 was found differentially expressed upon airway inflammation. Gene microarray showed TCF7 significantly down-regulated in CD4 $+\mathrm{T}$ cells from the inflamed lung of SPC-HA/TCR-HA mice compared with the lung of healthy TCR-HA donors, while no expression difference was detected in CD4 $+\mathrm{T}$ cells from the spleen of the same mice [119]. It seemed to be a potential relationship between TCF7 and airway inflammation, however, the research did not clarify the different isoforms of TCF7, and did not show the expression difference between the FL-TCF7 that promotes Th2 response and dn-TCF7 that repressed by Th2-polarized lymphocytes. Both Th2 and ILC2 cells are lymphocytes associated with type 2 immunity, which is characterized by high antibody titers and is responsible for the development of asthma and other allergic inflammatory diseases through releasing Th2type cytokines. Th2-polarized cells down-regulates the expression of dn-TCF7. Therefore, dn-TCF7 could probably be selected as a biomarker for airway inflammation [120]. Since FL-TCF7 promotes type 2 immunity, it could be a candidate gene target for anti-inflammatory therapy. 


\section{Allergy and asthma}

TCF7 resides on human chromosome 5q31.1, where was proposed as a candidate loci associated with asthma and allergy through genome-wide screens [121]. Both Th2 cells and ILC2 cells promoted by TCF7 were found to be involved in asthma. An experimental model of allergic asthma induced by ovalbumin in mice showed TCF7 was required in the production of the Th2 cytokine, IL-4. The TCF7-deficient mice produce less IL- 4 and showed less inflammation around airways, while the normal mice showed more inflammatory cell infiltration in perivascular and peribronchial areas after the challenge with ovalbumin. A diminished GATA3-1b expression was also detected in TCF7-deficient mice, suggesting that TCF7 induce IL-4 through GATA-3 pathway and contribute the development of airway inflammation [41]. ILC2 induced by TCF7 also contributes to Th2 response, and is closely related to asthma. A recent study found that during experimental asthma, ILC2 proliferate and produce IL-13, which contributes to allergy and worsen the condition of asthma [122]. The deficiency of TCF7 will lead to the lack of ILC2, and contribute relieving type 2 inflammations. Therefore, inhibition of TCF7 in the airway may play a protective role in allergic asthma, and might be considered as a promising target for the future treatment of asthma.

\section{Acute lung injury}

TCF7 expression was up-regulated in mice models of acute lung injury, accompanied by the increased $\beta$-catenin protein levels in nuclear localization [98]. $\beta$-catenin was suggested to play an important role in the repair phase after lung injury. The fibroproliferative repair was initiated and regulated by the non-canonical $E$-cadherin- $\beta$-catenin axis after lung injury induced by butylated hydroxytoluene/hyperoxia, through the regulation of the epithelial proliferation and lung matrix remodeling. The cytoplasma levels of E-cadherin decreased and the nuclear levels of $\beta$-catenin increased with an increasing expression of the cotranscriptional regulators, e.g. TCF7, TCF7L1, or target genes including cyclin D1 6 days after the induction of acute lung injury [98]. The expression of $\beta$-catenin increased in type II alveolar epithelial cells in animals with acute lung injury [123], probably different from the mechanism by which $\beta$-catenin was found to be involved in the repair and remodeling processes in patients with idiopathic pulmonary fibrosis [124]. In addition to the involvement of E-cadherin, the Wnt pathway was proposed as one of the signaling pathways involved in the repair phase after lung injury, evidenced by the finding that Wnt regulated lung morphogenesis and development [125]. However, it was found that the $\beta$-catenin was not necessary for the maintenance or efficient repair of the bronchiolar epithelium, since the knockout of $\beta$-catenin failed to affect the repair of the naphthalene-injured airway [99]. It indicates that other pathways may be involved in the repair process after lung injury, which should be furthermore clarified in future studies.

\section{COPD/emphysema}

COPD is the third leading cause of death worldwide, characterized by irreversible airflow obstruction and loss of functional pulmonary tissue [1]. Emphysema is the main feature of COPD with alveolar airspace enlargement, parenchymal tissue destruction, and impaired pulmonary regeneration [126]. Wnt/ $\beta$-catenin signaling was found to be related with lung development and repair after lung injury and was proposed as a pathway associated with emphysema. The activity of the $\mathrm{Wnt} / \beta$-catenin signaling pathway and the expression of its target genes, such as genes of TCF/LEF family, were observed decreased in lung tissues of patients with COPD or in experimental emphysema, where TCF7 even was not expressed $[127,128]$. Increased activation of Wnt/ $\beta$-catenin showed therapeutic effects in experimental emphysema by increasing pulmonary repair and decreasing airspace enlargement, attenuated the compromise of parenchymal tissues and restored the structure and function of alveolar epithelial cells [127]. These studies indicated that the up-regulation of the Wnt signaling pathway might be a therapeutic strategy for emphysema.

\section{Lung cancer}

$\mathrm{TCF} / \beta$-catenin-mediated transcription is an important regulator for carcinogenesis of diverse cells [37]. Among target genes of TCF/LEF family, cyclin D1 and c-myc are responsible for the decision between proliferation and apoptosis in the cells, and matrix metalloproteinase-7 (MMP-7) is related with tumor metastasis [80, 129]. Wnt/TCF pathway activation was clarified closely associated with the tumorogenesis, development and metastasis of lung cancer, and the metastatic capacity of lung adenocarcinoma cells could be suppressed by treatment with dominant negative mutants of TCF7 and TCF7L2, which suggested that the negative isoforms of TCF7 and TCF7L2 might be potential therapies for lung cancer [88].

\section{Conclusions}

TCF7 is one of important transcription factors for T cell development and differentiation, embryonic development, or tumorogenesis. Multiple TCF7 isoforms can be broadly divided into two groups: the full-length isoforms (FL-TCF7) as transcription activators, or dominant 
negative isoforms (dn-TCF7) as transcription repressors. TCF7 interacts with multiple proteins and target genes (e.g. CD3E, $\beta$-catenin, TCF7L2, LEF-1, IL-17, IL-4, or Eomes) and is involved in several signal pathways (e.g. Wnt, FoxO1, Notch, or P21pathways) which are critical for lung diseases, especially the canonical Wnt $/ \beta$ catenin pathway. TCF7 is suggested to be involved in immune responses to pathogens, autoimmune diseases, pulmonary infection, allergy, or asthma through promoting Th2 response, or the formation of memory CD8+ T cells. TCF7 also plays an important role in tissue repair and remodeling after acute lung injury or in the development of pulmonary fibrosis. The dual roles of TCF7 in lung cancers were discussed. FL-TCF7 is associated with the proliferation, invasion, or metastasis of lung cancer cells and the poor prognosis of patients with lung cancers, while dn-TCF7 shows therapeutic effect for cancer metastasis. Thus, TCF7 and TCF7-associated regulations play critical roles in the pathogenesis and development of lung diseases and should be considered as a new therapeutic target.

\begin{abstract}
Abbreviations
Bcr: breakpoint cluster region; cdk: cyclin-dependent kinase; CK1: casein kinase $1 \alpha$; COPD: chronic obstructive pulmonary disease; dnTCF1E: dominant negative E-tail isoform of TCF1; dnTCF7: dominant-negative isoform of TCF7; Dvl: disheveled; ETP: early thymic progenitor; Eomes: eomesodermin; FL-TCF7: full length isoform of TCF7; Fzd-LRP: frizzled-low-density lipoprotein receptorrelated protein; GATA3: GATA binding protein 3; GSK-3: glycogen synthase kinase-3 $\beta$; HMG: high mobility group; IL: interleukin; ILC: innate lymphoid cell; LEF: Iymphoid enhancer-binding factor; LEF-1: lymphoid enhancer-binding factor 1; MMP-7: matrix metalloproteinase-7; SFRP: secreted Frizzledrelated protein; STAT6: signal transducer and activator of transcription 6; TBC: TCF1 binding cluster; TCF-1: T cell-specific transcription factor-1; TCF7: transcription factor 7; TCF7L1: transcription factor 7-like 1; TCF7L2: transcription factor 7-like 2;WIF:Wnt inhibitory factor; WRE: Wnt response element.
\end{abstract}

\section{Authors' contributions}

XDW conceived of the study. YCZ collected and analyzed the data, interpreted the results, and drafted the manuscript. All authors read and approved the final manuscript.

\section{Acknowledgements \\ The work was supported by Shanghai Leading Academic Discipline Project (Project Number: B1 15), Zhongshan Distinguished Professor Grant (XDW), The National Nature Science Foundation of China (91230204, 81270099, 81320108001, 81270131), The Shanghai Committee of Science and Technol- ogy (12JC1402200, 12431900207, 11410708600), Zhejiang Provincial Natural Science Foundation (Z2080988), Zhejiang Provincial Science Technol- ogy Department Foundation (2010C14011), and Ministry of Education, Academic Special Science and Research Foundation for PhD Education (20130071110043)}

\section{Compliance with ethical guidelines}

\section{Competing interests}

The authors declare that they have no competing interests.

Received: 15 April 2015 Accepted: 27 July 2015

Published online: 20 August 2015

\section{References}

1. World Health Organization (2014) The top 10 causes of death. http:// www.who.int/mediacentre/factsheets/fs310/en/. Accessed July 2014

2. Health Ministry of China (2013) 2012 Chinese health statistical digest. http://www.moh.gov.cn/htmlfiles/zwgkzt/ptjnj/year2012/index2012. html. Accessed 28 Aug 2013

3. Babu MM, Luscombe NM, Aravind L, Gerstein M, Teichmann SA (2004) Structure and evolution of transcriptional regulatory networks. Curr Opin Struct Biol 14(3):283-291

4. Gill G (2001) Regulation of the initiation of eukaryotic transcription. Essays Biochem 37:33-43

5. Narlikar GJ, Fan HY, Kingston RE (2002) Cooperation between complexes that regulate chromatin structure and transcription. Cell 108(4):475-487

6. Xu L, Glass CK, Rosenfeld MG (1999) Coactivator and corepressor complexes in nuclear receptor function. Curr Opin Genet Dev 9(2):140-147

7. Shi Y, Lee JS, Galvin KM (1997) Everything you have ever wanted to know about Yin Yang 1. Biochimica et Biophysica Acta (BBA)-Rev Cancer. 1332(2):F49-F66

8. Tupler R, Green MR (1999) Transcription factors and human disease. Nat Med 5(5):481-482

9. Overington JP, Al-Lazikani B, Hopkins AL (2006) How many drug targets are there? Nat Rev Drug Discovery 5(12):993-996

10. van de Wetering M, Oosterwegel M, Dooijes D, Clevers H (1991) Identification and cloning of TCF-1, a T lymphocyte-specific transcription factor containing a sequence-specific HMG box. EMBO J 10(1):123

11. Schilham MW, Clevers H (eds) (1998) HMG box containing transcription factors in lymphocyte differentiation. In: Seminars in immunology. Elsevier

12. Wasmuth J, Bishop D, Westbrook C, Morrison K (1991) Report of the committee on the genetic constitution of chromosome 5. Cytogenet Genome Res 58(1-2):261-294

13. Van de Wetering M, Castrop J, Korinek V, Clevers H (1996) Extensive alternative splicing and dual promoter usage generate Tcf-1 protein isoforms with differential transcription control properties. Mol Cell Biol 16(3):745-752

14. Hurlstone A, Clevers H (2002) NEW EMBO MEMBER'S REVIEW: T-cell factors: turn-ons and turn-offs. EMBO J 21(10):2303

15. Willinger T, Freeman T, Herbert M, Hasegawa H, McMichael AJ, Callan MF (2006) Human naive CD8 T cells down-regulate expression of the WNT pathway transcription factors lymphoid enhancer binding factor 1 and transcription factor 7 ( $T$ cell factor- 1 ) following antigen encounter in vitro and in vivo. J Immunol 176(3):1439-1446

16. Roose J, Molenaar M, Peterson J, Hurenkamp J, Brantjes H, Moerer P et al (1998) The Xenopus Wnt effector XTcf-3 interacts with Grouchorelated transcriptional repressors. Nature 395(6702):608-612

17. Maier E, Hebenstreit D, Posselt G, Hammerl P, Duschl A, Horejs-Hoeck $\mathrm{J}$ (2011) Inhibition of suppressive T cell factor 1 (TCF-1) isoforms in naive CD4 + T cells is mediated by IL-4/STAT6 signaling. J Biol Chem 286(2):919-928

18. van de Wetering $M$, Oosterwegel $M$, Holstege $F$, Dooyes $D$, Suijkerbuijk $R$, van Kessel AG et al (1992) The human T cell transcription factor-1 gene. Structure, localization, and promoter characterization. J Biol Chem 267(12):8530-8536

19. Castrop J, van Wichen D, Koomans-Bitter $M$, van de Wetering $M$, de Weger R, van Dongen J et al (1995) The human TCF-1 gene encodes a nuclear DNA-binding protein uniquely expressed in normal and neoplastic T-lineage lymphocytes. Blood 86(8):3050-3059

20. Oosterwegel $M$, van de Wetering M, Timmerman J, Kruisbeek A, Destree O, Meijlink F et al (1993) Differential expression of the HMG box factors TCF-1 and LEF-1 during murine embryogenesis. Development. 118(2):439-448

21. Mayer K, Hieronymus T, Castrop J, Clevers H, Ballhausen W (1997) Ectopic activation of lymphoid high mobility group-box transcription factor TCF-1 and overexpression in colorectal cancer cells. Int J Cancer 72(4):625

22. Schweizer L, Rizzo C, Spires T, Platero JS, Wu Q, Lin T-A et al (2008) The androgen receptor can signal through $\mathrm{Wnt} / \beta$-Catenin in prostate cancer cells as an adaptation mechanism to castration levels of androgens. BMC Cell Biol 9(1):4 
23. Benhaj K, Akcali KC, Ozturk M (2006) Redundant expression of canonical Wnt ligands in human breast cancer cell lines. Oncol Rep 15(3):701-707

24. Weerkamp F, van Dongen J, Staal F (2006) Notch and Wnt signaling in T-lymphocyte development and acute lymphoblastic leukemia. Leukemia 20(7):1197-1205

25. Yu S, Zhou X, Steinke FC (2012) The TCF-1 and LEF-1 transcription factors have cooperative and opposing roles in $T$ cell development and malignancy. Immunity 37(5):813-826

26. Staal FJ, Clevers $H$ (2012) Tales of the unexpected: Tcf1 functions as a tumor suppressor for leukemias. Immunity 37(5):761-763

27. Tiemessen MM, Baert MR, Schonewille T, Brugman MH, Famili F, Salvatori DC et al (2012) The nuclear effector of Wnt-signaling, Tcf1, functions as a T-cell-specific tumor suppressor for development of lymphomas. PLOS Biol 10(11):e1001430

28. Jung KH, Yoon KJ, Song JH, Lee SH, Eun JW, Noh JH et al (2010) Loss-offunction mutations in the transcription factor 7 (T cell factor-1) gene in hepatogastrointestinal cancers. Mol Cell Toxicol 6(3):271-278

29. Najdi R, Syed A, Arce L, Theisen H, Ting J-H, Atcha F et al (2009) A Wnt kinase network alters nuclear localization of TCF-1 in colon cancer Oncogene 28(47):4133-4146

30. Roose J, Huls G, Van Beest M, Moerer P, van der Horn K, Goldschmeding R et al (1999) Synergy between tumor suppressor APC and the $\beta$-catenin-Tcf4 target Tcf1. Science 285(5435):1923-1926

31. Weber BN, Chi AW-S, Chavez A, Yashiro-Ohtani Y, Yang Q, Shestova O et al (2011) A critical role for TCF-1 in T-lineage specification and differentiation. Nature 476(7358):63-68

32. Zhao D-M, Yu S, Zhou X, Haring JS, Held W, Badovinac VP et al (2010) Constitutive activation of Wnt signaling favors generation of memory CD8 T cells. J Immunol 184(3):1191-1199

33. Yu Q, Erman B, Park J-H, Feigenbaum L, Singer A (2004) IL-7 receptor signals inhibit expression of transcription factors TCF-1, LEF-1, and ROR $\gamma \mathrm{t}$ impact on thymocyte development. J Exp Med 200(6):797-803

34. Eastman Q, Grosschedl R (1999) Regulation of LEF-1/TCF transcription factors by Wnt and other signals. Curr Opin Cell Biol 11(2):233-240

35. Ress A, Moelling K (2006) Bcr interferes with $\beta$-catenin-Tcf1 interaction. FEBS Lett 580(5):1227-1230

36. Ress A, Moelling K (2005) Bcr is a negative regulator of the Wnt signalling pathway. EMBO Rep 6(11):1095-1100

37. Choi KH, Park MW, Lee SY, Jeon M-Y, Kim MY, Lee HK et al (2006) IntracelIular expression of the T-cell factor-1 RNA aptamer as an intramer. Mol Cancer Ther 5(9):2428-2434

38. Ma J, Wang R, Fang X, Sun Z (2012) $\beta$-Catenin/TCF-1 pathway in T cell development and differentiation. J Neuroimmune Pharmacol 7(4):750-762

39. Cobas M, Wilson A, Ernst B, Mancini SJC, MacDonald HR, Kemler R et al (2004) $\beta$-catenin is dispensable for hematopoiesis and lymphopoiesis. J Exp Med 199(2):221-229

40. Koch U, Wilson A, Cobas M, Kemler R, MacDonald HR, Radtke F (2008) Simultaneous loss of $\beta$-and $\gamma$-catenin does not perturb hematopoiesis or lymphopoiesis. Blood 111(1):160-164

41. Yu Q, Sharma A, Oh SY, Moon H-G, Hossain MZ, Salay TM et al (2009) $T$ cell factor 1 initiates the Thelper type 2 fate by inducing the transcription factor GATA-3 and repressing interferon- $\gamma$. Nat Immunol 10(9):992-999

42. Ma J, Wang R, Fang X, Ding Y, Sun Z (2011) Critical role of TCF-1 in repression of the IL-17 gene. PLoS One 6(9):e24768

43. Oestreich KJ, Huang AC, Weinmann AS (2011) The lineage-defining factors T-bet and $\mathrm{BCl}-6$ collaborate to regulate Th1 gene expression patterns. J Exp Med 208(5):1001-1013

44. Paley MA, Wherry EJ (2010) TCF-1 flips the switch on Eomes. Immunity 33(2):145-147

45. Chang Y-J, Kim HY, Albacker LA, Baumgarth N, McKenzie ANJ, Smith DE et al (2011) Innate lymphoid cells mediate influenza-induced airway hyper-reactivity independently of adaptive immunity. Nat Immunol 12(7):631-638

46. Barlow JL, Bellosi A, Hardman CS, Drynan LF, Wong SH, Cruickshank JP et al (2012) Innate IL-13-producing nuocytes arise during allergic lung inflammation and contribute to airways hyperreactivity. J Allergy Clin Immun 129(1):191-198

47. Yang Q, Monticelli LA, Saenz SA, Chi AW-S, Sonnenberg GF, Tang J et al (2013) T cell factor 1 is required for group 2 innate lymphoid cell generation. Immunity 38(4):694-704
48. Prado-Garcia H, Aguilar-Cazares D, Meneses-Flores M, MoralesFuentes J, Lopez-Gonzalez JS (2008) Lung carcinomas do not induce T-cell apoptosis via the Fas/Fas ligand pathway but downregulate CD3 epsilon expression. Cancer Immunol Immunother 57(3):325-336

49. Kraus C, Liehr T, Hülsken J, Behrens J, Birchmeier W, Grzeschik K-H et al (1994) Localization of the human $\beta$-catenin gene (CTNNB1) to 3p21: a region implicated in tumor development. Genomics 23(1):272-274

50. Paul S, Dey A (2008) Wnt signaling and cancer development: therapeutic implication. Neoplasma. 55(3):165

51. Ioannidis V, Beermann F, Clevers H, Held W (2001) The $\beta$-catenin-TCF-1 pathway ensures CD4+ CD8+ thymocyte survival. Nat Immunol 2(8):691-697

52. van de Wetering $M$, Sancho E, Verweij $C$, de Lau W, Oving I, Hurlstone A et al (2002) The $\beta$-catenin/TCF-4 complex imposes a crypt progenitor phenotype on colorectal cancer cells. Cell 111(2):241-250

53. Shulewitz M, Soloviev I, Wu T, Koeppen H, Polakis P, Sakanaka C (2006) Repressor roles for TCF-4 and Sfrp1 in Wnt signaling in breast cancer. Oncogene 25(31):4361-4369

54. Wei W, Chua MS, Grepper S, So S (2010) Small molecule antagonists of Tcf4/ $\beta$-catenin complex inhibit the growth of HCC cells in vitro and in vivo. Int J Cancer 126(10):2426-2436

55. Cy $L$ (2005) Expression of T cell factor-4 in non-small-cell lung cancer. Chin Med J 118(2):136-140

56. Chen J, Yuan T, Liu M, Chen P (2013) Association between TCF7L2 gene polymorphism and cancer risk: a meta-analysis. PLoS One 8(8):e71730

57. Okamura RM, Sigvardsson M, Galceran J, Verbeek S, Clevers H, Grosschedl R (1998) Redundant regulation of T cell differentiation and TCR $\alpha$ gene expression by the transcription factors LEF-1 and TCF-1. Immunity 8(1):11-20

58. Giese K, Amsterdam A, Grosschedl R (1991) DNA-binding properties of the HMG domain of the lymphoid-specific transcriptional regulator LEF-1. Genes Dev 5(12b):2567-2578

59. Hovanes K, Li TW, Munguia JE, Truong T, Milovanovic T, Marsh JL et al (2001) $\beta$-catenin-sensitive isoforms of lymphoid enhancer factor-1 are selectively expressed in colon cancer. Nat Genet 28(1):53-57

60. Hirota K, Ahlfors H, Duarte JH, Stockinger B (2011) Regulation and function of innate and adaptive interleukin-17-producing cells. EMBO Rep 13(2):113-120

61. Kawaguchi M, Kokubu F, Fujita J, Huang S-K, Hizawa N (2009) Role of interleukin-17F in asthma. Inflamm Allergy-Drug Targets. 8(5):383-389

62. Doe C, Bafadhel M, Siddiqui S, Desai D, Mistry V, Rugman P et al (2010) Expression of the Thelper 17-associated cytokines IL-17A and IL-17F in asthma and COPD. CHEST Journal. 138(5):1140-1147

63. Kopf M, Le Gros G, Bachmann M, Lamers MC, Bluethmann H, Köhler $\mathrm{G}$ (1993) Disruption of the murine IL-4 gene blocks Th2 cytokine responses. Nature 362:245-248

64. Kuhn R, Rajewsky K, Muller W (1991) Generation and analysis of interleukin-4 deficient mice. Science 254(5032):707-710

65. Tepper RI, Levinson DA, Stanger BZ, Campos-Torres J, Abbas AK, Leder P (1990) IL-4 induces allergic-like inflammatory disease and alters T cell development in transgenic mice. Cell 62(3):457-467

66. Jain-Vora S, Wert SE, Temann U-A, Rankin JA, Whitsett JA (1997) Interleukin-4 alters epithelial cell differentiation and surfactant homeostasis in the postnatal mouse lung. Am J Respir Cell Mol Biol 17(5):541-551

67. Levings MK, Schrader JW (1999) IL-4 inhibits the production of TNF- $\alpha$ and IL-12 by STAT6-dependent and-independent mechanisms. J Immunol 162(9):5224-5229

68. Huaux F, Liu T, McGarry B, Ullenbruch M, Phan SH (2003) Dual roles of IL-4 in lung injury and fibrosis. J Immunol 170(4):2083-2092

69. Hebenstreit D, Giaisi M, Treiber MK, Zhang X-B, Mi H-F, Horejs-Hoeck J et al (2008) LEF-1 negatively controls interleukin-4 expression through a proximal promoter regulatory element. J Biol Chem 283(33):22490-22497

70. Intlekofer AM, Takemoto N, Wherry EJ, Longworth SA, Northrup JT, Palanivel VR et al (2005) Effector and memory CD8+ T cell fate coupled by T-bet and eomesodermin. Nat Immunol 6(12):1236-1244

71. Kohlmeier JE, Cookenham T, Roberts AD, Miller SC, Woodland DL (2010) Type I interferons regulate cytolytic activity of memory CD8 $<$ sup $>+</$ sup $>T$ Cells in the lung airways during respiratory virus challenge. Immunity 33(1):96-105 
72. Willert K, Jones KA (2006) Wnt signaling: is the party in the nucleus? Genes Dev 20(11):1394-1404

73. Kikuchi A, Yamamoto H, Kishida S (2007) Multiplicity of the interactions of Wnt proteins and their receptors. Cell Signal 19(4):659-671

74. Gordon MD, Nusse R (2006) Wnt signaling: multiple pathways, multiple receptors, and multiple transcription factors. J Biol Chem 281(32):22429-22433

75. MacDonald BT, Yokota C, Tamai K, Zeng X, He X (2008) Wnt signal amplification via activity, cooperativity, and regulation of multiple intracellular PPPSP motifs in the Wnt co-receptor LRP6. J Biol Chem 283(23):16115-16123

76. Nusse R (1999) WNT targets: repression and activation. Trends Genet 15(1):1-3

77. Moon RT, Bowerman B, Boutros M, Perrimon N (2002) The promise and perils of Wnt signaling through $\beta$-catenin. Science 296(5573):1644-1646

78. Vlad A, Röhrs S, Klein-Hitpass L, Müller O (2008) The first five years of the Wnt targetome. Cell Signal 20(5):795-802

79. Königshoff M, Eickelberg O (2010) WNT signaling in lung disease: a failure or a regeneration signal? Am J Respir Cell Mol Biol 42(1):21-31

80. He T-C, Sparks AB, Rago C, Hermeking H, Zawel L, da Costa LT et al (1998) Identification of c-MYC as a target of the APC pathway. Science 281(5382):1509-1512

81. Yan D, Wiesmann M, Rohan M, Chan V, Jefferson AB, Guo L et al (2001) Elevated expression of axin2 and hnkd mRNA provides evidence that Wnt/ $\beta$-catenin signaling is activated in human colon tumors. Proc Natl Acad Sci 98(26):14973-14978

82. Niida A, Hiroko T, Kasai M, Furukawa Y, Nakamura Y, Suzuki Y et al (2004) DKK1, a negative regulator of Wnt signaling, is a target of the $\beta$-catenin/ TCF pathway. Oncogene 23(52):8520-8526

83. Chen S, Guttridge DC, You Z, Zhang Z, Fribley A, Mayo MW et al (2001) Wnt-1 signaling inhibits apoptosis by activating $\beta$-catenin $/ T$ cell factormediated transcription. J Cell Biol 152(1):87-96

84. You L, He B, Xu Z, Uematsu K, Mazieres J, Mikami I et al (2004) Inhibition of Wnt-2-mediated signaling induces programmed cell death in nonsmall-cell lung cancer cells. Oncogene 23(36):6170-6174

85. Winn RA, Van Scoyk M, Hammond M, Rodriguez K, Crossno JT, Heasley LE et al (2006) Antitumorigenic effect of Wnt 7a and Fzd 9 in nonsmall cell lung cancer cells is mediated through ERK-5-dependent activation of peroxisome proliferator-activated receptor $\gamma$. J Biol Chem 281(37):26943-26950

86. Uematsu K, He B, You L, Xu Z, McCormick F, Jablons DM (2003) Activation of the Wnt pathway in non small cell lung cancer: evidence of dishevelled overexpression. Oncogene 22(46):7218-7221

87. Tang M, Torres-Lanzas J, Lopez-Rios F, Esteller M, Sanchez-Cespedes M (2006) Wnt signaling promoter hypermethylation distinguishes lung primary adenocarcinomas from colorectal metastasis to the lung. Int $J$ Cancer 119(11):2603-2606

88. Nguyen DX, Chiang AC, Zhang XH-F, Kim JY, Kris MG, Ladanyi M et al (2009) WNT/TCF signaling through LEF1 and HOXB9 mediates lung adenocarcinoma metastasis. Cell 138(1):51-62

89. Hommura F, Furuuchi K, Yamazaki K, Ogura S, Kinoshita I, Shimizu M et al (2002) Increased expression of $\beta$-catenin predicts better prognosis in nonsmall cell lung carcinomas. Cancer 94(3):752-758

90. Retera J, Leers M, Sulzer MA, Theunissen P (1998) The expression of beta-catenin in non-small-cell lung cancer: a clinicopathological study. J Clin Pathol 51(12):891-894

91. Choi YS, Shim YM, Kim S-H, Son DS, Lee H-S, Kim GY et al (2003) Prognostic significance of E-cadherin and $\beta$-catenin in resected stage I non-small cell lung cancer. Eur J Cardiothorac Surg 24(3):441-449

92. Selman M, Pardo A, Kaminski N (2008) Idiopathic pulmonary fibrosis: aberrant recapitulation of developmental programs? PLoS Med 5(3):e62

93. Kaminski N, Rosas IO (2006) Gene expression profiling as a window into idiopathic pulmonary fibrosis pathogenesis: can we identify the right target genes? Proc Am Thorac Soc 3(4):339

94. Selman M, Pardo A, Barrera L, Estrada A, Watson SR, Wilson K et al (2006) Gene expression profiles distinguish idiopathic pulmonary fibrosis from hypersensitivity pneumonitis. Am J Respir Crit Care Med 173(2):188

95. Yang IV, Burch LH, Steele MP, Savov JD, Hollingsworth JW, McElvaniaTekippe E et al (2007) Gene expression profiling of familial and sporadic interstitial pneumonia. Am J Respir Crit Care Med 175(1):45
96. Zuo F, Kaminski N, Eugui E, Allard J, Yakhini Z, Ben-Dor A et al (2002) Gene expression analysis reveals matrilysin as a key regulator of pulmonary fibrosis in mice and humans. Proc Natl Acad Sci 99(9):6292-6297

97. Königshoff M, Balsara N, Pfaff E-M, Kramer M, Chrobak I, Seeger W et al (2008) Functional Wnt signaling is increased in idiopathic pulmonary fibrosis. PLoS One 3(5):e2142

98. Douglas IS, del Valle FD, Winn RA, Voelkel NF (2006) $\beta$-Catenin in the fibroproliferative response to acute lung injury. Am J Respir Cell Mol Biol 34(3):274

99. Zemke AC, Teisanu RM, Giangreco A, Drake JA, Brockway BL, Reynolds SD et al (2009) $\beta$-Catenin is not necessary for maintenance or repair of the bronchiolar epithelium. Am J Respir Cell Mol Biol 41(5):535

100. Huang H, Tindall DJ (2007) Dynamic FoxO transcription factors. J Cell Sci 120(15):2479-2487

101. Schmidt M, de Mattos SF, van der Horst A, Klompmaker R, Kops GJL, Lam EW-F et al (2002) Cell cycle inhibition by FoxO forkhead transcription factors involves downregulation of cyclin D. Mol Cell Biol 22(22):7842-7852

102. Burgering BM, Medema RH (2003) Decisions on life and death: FOXO Forkhead transcription factors are in command when PKB/Akt is off duty. J Leukoc Biol 73(6):689-701

103. Greer EL, Brunet A (2005) FOXO transcription factors at the interface between longevity and tumor suppression. Oncogene 24(50):7410-7425

104. Sangodkar J, Dhawan NS, Melville H, Singh VJ, Yuan E, Rana H et al (2012) Targeting the FOXO1/KLF6 axis regulates EGFR signaling and treatment response. J Clin Investig 122(7):2637

105. Maekawa T, Maniwa Y, Nishio W, Yoshimura M, Ohbayashi C, Hayashi Y et al (2009) Expression and localization of FOXO1 in non-small cell lung cancer. Oncol Rep 22(1):57-64

106. Kim MV, Ouyang W, Liao W, Zhang MQ, Li MO (2013) The transcription factor foxo 1 controls central-memory CD8(+) T cell responses to infection. Immunity 39(2):286-297. doi:10.1016/j.immuni.2013.07.013

107. Ouyang W, Liao W, Luo CT, Yin N, Huse M, Kim MV et al (2012) Novel Foxo1-dependent transcriptional programs control Treg cell function. Nature 491(7425):554-559

108. Tejera MM, Kim EH, Sullivan JA, Plisch EH, Suresh M (2013) FoxO1 controls effector-to-memory transition and maintenance of functional CD8 T cell memory. J Immunol 191(1):187-199

109. Miele L (2006) Notch signaling. Clin Cancer Res 12(4):1074-1079

110. Amsen D, Blander JM, Lee GR, Tanigaki K, Honjo T, Flavell RA (2004) Instruction of distinct CD4 T helper cell fates by different notch ligands on antigen-presenting cells. Cell 117(4):515-526

111. Germar K, Dose M, Konstantinou T, Zhang J, Wang H, Lobry C et al (2011) T-cell factor 1 is a gatekeeper for T-cell specification in response to Notch signaling. Proc Natl Acad Sci 108(50):20060-20065

112. Carlin SM, Khoo ML, Ma DD, Moore JJ (2012) Notch signalling inhibits CD4 expression during initiation and differentiation of human $T$ cell lineage. PLoS One 7(10):e45342

113. Rothenberg EV (2012) Transcriptional drivers of the T-cell lineage program. Curr Opin Immunol 24(2):132-138

114. Yu S, Xue H-H (2013) TCF-1 mediates repression of Notch pathway in T lineage-committed early thymocytes. Blood 121(19):4008-4009

115. Shoji T, Tanaka F, Takata T, Yanagihara K, Otake Y, Hanaoka N et al (2002) Clinical significance of p21 expression in non-small-cell lung cancer. J Clin Oncol 20(18):3865-3871

116. Marchetti A, Doglioni C, Barbareschi M, Buttitta F, Pellegrini S, Bertacca G et al (1996) p21 RNA and protein expression in non-small cell lung carcinomas: evidence of p53-independent expression and association with tumoral differentiation. Oncogene 12(6):1319-1324

117. Hoverter NP, Ting J-H, Sundaresh S, Baldi P, Waterman ML (2012) A WNT/ p21 circuit directed by the C-clamp, a sequence-specific DNA binding domain in TCFs. Mol Cell Biol 32(18):3648-3662

118. Kamei J, Toyofuku T, Hori M (2003) Negative regulation of p21 by $\beta$-catenin/TCF signaling: a novel mechanism by which cell adhesion molecules regulate cell proliferation. Biochem Biophys Res Commun 312(2):380-387

119. Bruder D, Westendorf AM, Geffers R, Gruber AD, Gereke M, Enelow RI et al (2004) CD4 T lymphocyte-mediated lung disease: steady state between pathological and tolerogenic immune reactions. Am J Respir Crit Care Med 170(11):1145-1152 
120. Spellberg B, Edwards JE (2001) Type 1/Type 2 immunity in infectious diseases. Clin Infect Dis 32(1):76-102

121. Ober C (2001) Susceptibility genes in asthma and allergy. Curr Allergy Asthma Rep 1:174-179

122. Scanlon ST, McKenzie ANJ (2012) Type 2 innate lymphoid cells: new players in asthma and allergy. Curr Opin Immunol 24(6):707-712

123. Reddy R, Buckley S, Doerken M, Barsky L, Weinberg K, Anderson KD et al (2004) Isolation of a putative progenitor subpopulation of alveolar epithelial type 2 cells. Am J Physiol-Lung Cell Mol Physiol 286(4):L658-L667

124. Chilosi M, Poletti V, Zamò A, Lestani M, Montagna L, Piccoli P et al (2003) Aberrant Wnt/B-catenin pathway activation in idiopathic pulmonary fibrosis. Am J Pathol 162(5):1495-1502
125. Shannon JM, Hyatt BA (2004) Epithelial-mesenchymal interactions in the developing lung. Annu Rev Physiol 66:625-645

126. Minai OA, Benditt J, Martinez FJ (2008) Natural history of emphysema. Proc Am Thorac Soc. 5(4):468

127. Kneidinger N, Yildirim AO, Callegari J, Takenaka S, Stein MM, Dumitrascu Ret al (2011) Activation of the WNT/ $\beta$-catenin pathway attenuates experimental emphysema. Am J Respir Crit Care Med. 183(6):723-733

128. Godtfredsen N, Lam T, Hansel T, Leon M, Gray N, Dresler C et al (2008) COPD-related morbidity and mortality after smoking cessation: status of the evidence. Eur Respir J 32(4):844-853

129. Tetsu O, McCormick F (1999) $\beta$-Catenin regulates expression of cyclin D1 in colon carcinoma cells. Nature 398(6726):422-426
Submit your next manuscript to BioMed Central and take full advantage of:

- Convenient online submission

- Thorough peer review

- No space constraints or color figure charges

- Immediate publication on acceptance

- Inclusion in PubMed, CAS, Scopus and Google Scholar

- Research which is freely available for redistribution

Submit your manuscript at www.biomedcentral.com/submit 